\title{
Frederick Egmondt, an English Fifteenth Century Stationer.
}

THE year 1493, either by chance or from some cause of which we are at present ignorant, seems to have been an important period in the history of printing in England. After 1486 all the English presses had with one exception ceased working; the printers at Oxford and St. Albans and Machlinia in London, had disappeared, and only Caxton at Westminster was left; but in 1493 appeared the first dated books from the presses of Wynkyn de Worde, Caxton's successor, and Richard Pynson the successor of Machlinia. But a stronger sign of the revival of printing and of an increased demand for books was afforded by the appearance in England during this year of two important and wealthy foreign booksellers, Frederick Egmondt and Nicolas Lecompte, who offered for sale books printed at their expense in Italy and France.

The name of Frederick Egmondt appears for the first time in the colophon of the York Breviary of 1493:- "Singulari cura ac diligentia impensisque Friderici Egmundt bene revisum emendatumque; feliciter est explicitum. Impressum venetiis, per Johannem de Landoia dictus Hertzog; limpidissimis, ut cernitur, caracteribus, \&c." The book is an octavo of 464 leaves, and one copy only is known, now in the Bodleian [Gough Missals 6].

Egmondt during the first few years of his business employed no press but that of Hertzog, and we do not know of any books by this printer produced for any other English bookseller, so that as regards liturgical books for English use known to us now only from fragments, we are justified, I think, in attributing to Egmondt as bookseller, such as we can determine from their type to have been printed by Hertzog.

Two fragments of different editions of the Sarum Breviary, printed by this printer about I493-4 are known, both in octavo. The earlier of the two is in the library of St. John's College, Cambridge, the other in the library at Lambeth Palace; of the former eight leaves are known, of the latter four, and in both cases they have been used to line the bindings of books. In the library of Corpus Christi College, Oxford, is another fragment, luckily containing the title, which may belong to the 
second of the above-mentioned editions, or be a portion of a third edition. Like the others, this fragment has been used to line the boards of a binding.

This number of editions points to a large demand for service books, and no doubt Egmondt's venture was successful, for we find him in the following year, I494, in company with another stationer, Gerard Barrevelt, employing the Venice press to print for him two editions of the Sarum Missal, one in folio issued in August, the other in octavo issued in December.

The folio edition is a book of extraordinary rarity, only two imperfect copies being known, one in the University Library of Bologna, and another which was bought by Quaritch from $\mathrm{Mr}$. Sherbrooke's collection. The title-page and colophon of a third copy are amongst the Bodleian fragments, and various odd leaves are in other collections. Hain [ II422] quotes a copy which he had not seen and which wanted the title.

On the title-page we find the device of Egmondt and Barrevelt, which though of a very ordinary type is remarkable for the delicacy of its execution. It consists of a circle divided by a perpendicular line produced beyond the top of the circle, the projection being crossed by two bars. In the left hand division of the circle are the initials and mark of Egmondt, in the right hand those of Barrevelt. The whole is enclosed in a square frame and the background is filled with arabesque floral designs. The appearance and execution of this device and its manifest likeness to Hertzog's, point to its having been cut in Venice.

The octavo Missal of 1494 is a much commoner book at least a dozen copies being known; but it is a very beautiful little volume, and contains perhaps the most gracefully designed initial letters to be found in any early printed book. On the last page is the mark of Hertzog, and below it the inscription "Fredericus Egmont me fieri fecit." There is no mention of Barrevelt in the colophon, so that perhaps this edition was undertaken by Egmondt alone; the absence of the double device which had been used in the folio edition favours this conjecture.

In 1495, Hertzog printed another Sarum Breviary in $16^{\circ}$, for Egmondt and Barrevelt, whose double device is found in it, although Egmondt's name alone appears in the colophon. The Pars Estivalis only is known of this edition, and of this there is but one copy which is in the Bodleian [Gough Missals 43]; a few leaves are in the library of Brazenose College, Oxford. 
This book ends the series of Egmondt's Venice printed books so far as we know, but considering their extraordinary rarity and the fact that several editions are known only from fragments rescued from the bindings of books, we may hope and reason. ably expect that evidences of other editions may be found.

After I495, we lose sight of Egmondt till 1499. He was then no longer associated with Gerard Barrevelt, but was in partnership with a man whose name given in a Latin form was Peter post Pascham. It seems to have been a common custom with printers and booksellers to Latinize their names when they issued Latin books, or books with Latin colophons, and this habit has been a fruitful source of confusion to bibliographers. The striking instance mentioned in one of Mr. Bradshaw's papers will be familiar to most readers-the identity of Godfried van der Haghen with Godfridus Dumæus. In the case of Peter post Pascham, all ingenuity seems unavailing, and no reasonable guess has yet been made at his real name.

These two stationers employed Pynson to print for them an edition of the Medulla grammatice or Promptorium puerorum, a folio of I 6 leaves, and one of the ugliest books which issued from Pynson's press.

After 1499, we lose sight of Egmondt as a publisher for a considerable time, but we have evidence of his industry in another branch of his trade, that of bookbinding, which was considered at that time part of the business of a bookseller.

Two panel stamps bearing his mark or name are known, and both seem from their appearance to have been cut about the beginning of the sixteenth century. The first has as its central ornament the Tudor rose, and round it are vine leaves in an oblong compartment; round the whole is an arabesque floral border containing the initials and mark of Egmondt. This design was common at the time, there being several other panels almost identical, one of which was used by Pynson. The second and more important panel is an almost exact copy of the device of Philippe Pigouchet, the Paris printer. A "wild" man and woman standing on either side of a tree covered with some kind of fruit, bear in one hand flowering boughs, while with the other they assist in supporting a shield suspended by a belt from the branches above them upon the shield are Egmondt's mark and initals. The device of the wild man and woman was for some reason very popular at this time and for a short period afterwards: it was used, as Dr. 
Dickson has pointed out in his Introduction of Printing into Scotland, by Bumgart at Cologne, and at Edinburgh, by Walter Chepman and Thomas Davidson. It was used by Pigouchet and other Parisian printers, and by Peter Treveris, who printed in Southwark at the sign of the "Wodows," and the references to it in colophons are very numerous. This panel of Egmondt's not only bears his mark and initials, but is inscribed on the lower margin " Fredericus Egmondt me f [ecit]." Only two specimens are known, one in the library at Caius College, the other in Corpus Christi College, Cambridge: the former is in excellent preservation, as clear as when it was first finished, the latter is so rubbed as to be almost undecipherable. Both these books are ornamented on the reverse with a panel containing three rows of arabesques of foliage surrounded by a boruir having ribbons in the upper and lower portion inscribed with the names of the four Evangelists. The dates of the two books above-mentioned are c. I505 and 1521, but the appearance and style of the stamps used point to their having been cut about 1500. Binders' stamps, being formed of strong material, were practically indestructible, so that we often find them in use long after their original owner was dead.

It is curious that bibliographers should have so persistently neglected the study of stamped bindings, since they are often of the greatest importance as the means of supplying valuable evidence. When they have not been tampered with they are generally lined with printed fragments, often of great rarity, and still more valuable for the light they throw on the history of the individual book. Mr. Bradshaw, at the end of his memorandum (No. 6), On a Fragment of the Fifteen Oes, quotes a few of the many important results that he had arrived at from the examination of old bindings, but as he says there, " it is a new field of enquiry altogether," and it is still almost unworked.

During the first twenty years of the sixteenth century, Egmondt entirely disappears, but there are a series of books, printed at Paris about the end of this interval, which were evidently produced for him. Perhaps the earliest is an edition of Virgil, a copy of which is in the British Museum [c. 48. a]. It is a $16^{\circ}$ (not a $24^{\circ}$ as stated in the catalogue), of 288 leaves $\left(a-z, A-N^{8}\right)$, and contains a number of full-page woodcuts, inserted, as the preface tells us, for the purpose of aiding the memory of students, and as a further assistance, the names 
the various characters are inserted beside each of them in capital letters. These illustrations strongly resemble in style those produced at a little earlier period at Strasburg, and are entirely unlike the Paris cuts of the time. This edition is mentioned by Brunet [ed. 1863 , v. I279], who quotes a copy in the catalogue of the collection of M. Riva de Milan, sold in 1856 for 255 francs, which is probably the same copy as that now in the Museum. In addition to his description he gives a facsimile of the device from the last leaf, calling it, however, that of an " imprimeur inconnu." It is almost identical with and evidently copied from that used in the I494 Missal, except that the dead background of the original is here heightened with dots in the French style, and the foliage slightly more elaborated. Egmondt's mark and initials are the same as in the original, but Barrevelt's mark is gone, and its place taken by a new mark and the initials I. B. ; with our present knowledge, however, it is impossible to determine to whom these initials refer.

Brunet mentions also an edition of Richard Maidston's Sermons, entitled Dormi Secure bearing the same mark, printed at Paris in $1527,8^{\circ}$, but he does not refer to any copy.

In the British Museum [627. a. 3] is a copy of another edition, printed at Paris in $15^{20}$. It is an $8^{\circ}$ of 316 leaves in two divisions. The first, containing the Sermones de Tempore, has 124 leaves $\left(a \cdot p^{8}, q^{4}\right)$; the second, containing the Sermones de Sanctis, has 192 leaves (a-z \& $\left.{ }^{8}\right)$. Egmondt's mark is upon the title page, and below it we find, "Venundantur Parrhisius in vico sancti Jacobi," which would lead us to suppose that Egmondt had left London to settle in Paris.

The last of the series of books bearing Egmondt's device is an edition of the Heures a l'usaige de Romme, printed at Paris not earlier than $152 \mathrm{r}$, since the calendar only begins with that year. It is an $8^{\circ}$ of 112 leaves $\left(\mathrm{A}-\mathrm{O}^{8}\right)$. The copy in the British Museum, the only one I have seen, is printed on vellum, and the cuts and initial letters throughout the whole book are illuminated in gold and colours. This may, in the opinion of some, increase the beauty of the book, but it ruins it for purposes of comparison, since it is impossible to trace even the strongest lines of the woodcut through the thick coating of body colour which forms the ground of such illuminations. Its binding is of olive morocco, the work evidently of one of the Eves, and in the centre and corner of the sides are impressed the initials of a former owner. 
Upon the last page is a very curious pictorial rabus of nine lines. The first five are not uncommon in Paris printed service books, especially in those printed for Guillaume Godard, but they were considered so difficult to decipher even at the time, that a translation in ordinary type was subjoined. This is found also in the present book, but unfortunately no translation of the last four lines has been added, so that their meaning is still hidden, for without some such assistance it seems impossible to solve the riddle. From a word or two which can be made out here and there, we can see that the lines are merely moral maxims, and do not contain the name of the printer, so that their solution is not of much importance.

None of the last four books contain either the name of the printer, or any reference to the sign where they were printed or sold. The only information they give is that they were printed at Paris, and one adds further, "Venundantur Parrhisius in vico sancti Jacobi," which hardly helps us, seeing that the Rue St. Jacques, in the vicinity of the University, was in great part occupied by stationers, booksellers, and printers. They are all the work of one printer, as we can see from the type, which in many ways resembles that of Lyons rather than Paris; but further than this we cannot go at present, for the varieties of type then used in France were so numerous, and so little has yet been done to distinguish them, that it is impossible in many cases to assign particular books to any individual printer. The work done by M. Harrisse in the introduction to his Excerpta Columbiniana on this subject is remarkably good, but does not extend far enough to help us in this particular case.

It is much to be regretted that so little is known about these early stationers, especially such as were important enough to have books printed at their expense, for we can hardly get a clear insight into the history of English printing till we know more about these men who had such an influence upon it. Their importation of foreign books, and the consequent competition, changed entirely the aspect of the book trade, and until the passing of the Act of 1535 materially cramped home production.

Before that time, under the Act of 1483 , there were no restrictions against foreign competition, indeed the Act tended rather to encourage it, and many foreign hooksellers, especially those of Rouen, paid periodical visits to England to sell their books at the fairs. Examining such a document as the Day-book 
of John Dorne, bookseller in Oxford, in 1520 ,* we see how large a proportion of a bookseller's stock consisted of foreign printed books, and can understand the growing feeling against their importation which led to the Act of 1535 .

I have ventured to put together these facts about Egmondt, which I trust may not be considered entirely without interest, in the hope of eliciting some further information. As will be seen we know yet but little about him, but even that little has never been put on record, and until we have some foundation on which to collect our scattered information we can make but small use of it. Once get facts together so that they can throw light upon each other, and their value is increased a hundredfold. As our greatest bibliographer has said, "What is wanted for the solution of a bibliographical problem is not ingenuity of speculation, but simply honest and patient observation of facts allowed to speak for themselves."

E. Gordon Duff.

"Edited by Falconer Madan, Esq., Sub-librarian of the Bodleian, and published by the Oxford Historical Society, Vol. 5.-Collectanea, Vol. I.

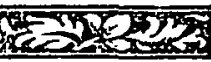

